\title{
Lipoma HMGIC Fusion Partner
}

National Cancer Institute

\section{Source}

National Cancer Institute. Lipoma HMGIC Fusion Partner. NCI Thesaurus. Code C97609.

Lipoma HMGIC fusion partner (200 aa, $22 \mathrm{kDa}$ ) is encoded by the human LHFPL6 gene.

This protein may play a role in the modulation of cell proliferation or cell adhesion. 